\title{
The Partisan Politics of Higher Education
}

\author{
Julian L. Garritzmann, University of Konstanz and University of Zurich
}

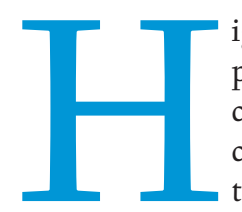
igher education is a mixed blessing: it can promote equality of opportunity, foster educational and socioeconomic upward mobility, contribute to countries' knowledge production and economic growth, and even lead to higher levels of health and life satisfaction. However, higher education also can be a tool of the reproduction of existing elites, it can plunge students into lifelong debt, and it can cause "negative redistribution" from the poor to the rich because the better-off are more likely to benefit from publicly funded college. Thus, depending on the composition of an existing education system, higher education can either mitigate or reinforce prevailing social, economic, and educational inequalities.

These complex (re)distributive dynamics make higher education an extremely interesting and relevant field of study for political scientists, particularly regarding the role of political parties. Do left-wing parties expand higher education (i.e., spending) because of its progressive implications, or are right-wing parties the main proponent because of its regressive consequences?

This article reviews the state of the art of the existing country-comparative literature on the partisan politics of higher education in advanced democracies. I argue that important variations in higher-education systems can be understood only by considering the partisan politics behind these regimes. The argument and the literature on which it is based are presented as follows. I begin by discussing early studies inspired by welfare-state research, positing that parties have continuously exercised strong influence on higher-education systems. The main question in this literature was whether leftwing or right-wing parties expand higher education. Second, I turn to newer approaches, arguing that the effect of parties is not this simple and linear but rather conditional on the status quo of the specific education system and the type of spending. Third, against this background, I examine approaches claiming that the impact of parties on higher-education policy has decreased over time, which is attributed to positive feedback effects resulting in path dependencies.

The article concentrates on comparative work of the advanced economies between 1945 and 2015, which is mainly quantitative because it focuses on quantifiable comparable outcomes, such as public spending and enrollment levels. This international perspective helps in understanding the complex politics of higher education and provides lessons for policy makers and practitioners around the globe. Yet, this perspective also has blind spots, and I outline both for future research in the concluding section.

\section{THE PROGRESSIVE NATURE OF HIGHER EDUCATION: A TOPIC OF THE POLITICAL LEFT?}

Comparative political scientists neglected education policies for a long time (for detailed reviews, see Busemeyer and Trampusch [2011] and Iversen and Stephens [2008]). When they finally discovered the field in the 1990s, the first comparative analyses derived expectations from welfarestate research and hypothesized that the politics of education resemble those of other social policies. That is, in line with Power Resource Theory, left-wing governments were expected to expand public-education spending because education fosters equality of opportunity, social upward mobility, and redistribution (Castles 1989). Similarly, education spending in left-wing-dominated Scandinavia is much higher than under conservative rule in Continental and Southern Europe. Boix (1998) argued, moreover, that the Left's focus on education should even strengthen over time because, in a globalized world, their demand-side-oriented Keynesian policies become ineffective. Looking for new strategies to pursue their goals, leftist parties therefore would increasingly focus on supply-side policies-education being a prime example. Adding to this reasoning, Busemeyer (2009) maintained that Social Democrats since the 1980 os increasingly tried to attract middle-class voters and therefore emphasized higher education as a means to appeal to their interests.

In short, a consensus among scholars inspired from welfarestate research was that the politics of higher education closely resemble those of other social policies; that is, left-wing parties spend more on education. (See Garritzmann and Seng [2016] for a more encompassing literature review on the role of political parties in education policy.)

\section{THE REGRESSIVE NATURE OF HIGHER EDUCATION: A TOPIC OF THE POLITICAL RIGHT?}

Higher education, however, has characteristics that challenge the notion that public spending has progressive redistributive consequences in the interest of left-wing parties and their voters. As a broad socioeconomic literature demonstrates (Breen and Jonsson 2005), access to higher education historically has been-and remains until present day-dependent on parental background in all advanced democracies. The children of richer and better-educated parents are more likely to attend universities than their less-privileged classmates; moreover, 
they are more likely to study in more prestigious institutions and programs. ${ }^{1}$ Although the size of this effect differs across countries and time, the general pattern is clear: access to higher education is stratified by parental background.

Consequently, public spending on higher-education institutions, in fact, is not fiscally progressive but rather regressive because the children of better-off families benefit disproportionally from public tax money, resulting in negative redistribution from the poor to the rich (Fernandez and Rogerson 1995). Notably, Karl Marx criticized this fact 120 years ago: "When in some countries higher-education institutions are 'free-ofcharge,' this only means covering the rich offspring's education costs from public tax coffers" (Marx 1973 [1890/1891]; my translation). It is this fact that makes the politics of higher education such a fascinating and relevant but also complex phenomenon. In this sense, Wilensky's $(1975,3)$ dictum that, compared to other social policies, "education is special" applies particularly to higher education. spending (i.e., tuition fees) so that students at least pay partly for their own education.

When enrollment levels become more universal and lowerstrata children have a realistic chance of achieving access to college, however, Ansell reasons that the partisan dynamics reverse. In this scenario, left-wing parties should favor further expansion to enable their constituency to attend college. Right-wing parties, in contrast, now oppose further expansion because they prefer to keep higher education exclusive. In short, "the impact of partisanship is conditional" on the enrollment level and changes over time (Ansell 2008, 191).

\section{Disaggregating Types of Spending}

Overall, the "conditional-partisan-effect model" is straightforward and a great approach to start dissolving the earlier contradictory findings. The model's blind spot, however, is how enrollment levels change in the first place. Enrollment is the crucial mediating variable, fundamentally changing the politics

\section{Consequently, public spending on higher-education institutions, in fact, is not fiscally progressive but rather regressive because the children of better-offfamilies benefit disproportionally from public tax money, resulting in negative redistribution from the poor to the rich (Fernandez and Rogerson 1995).}

Against this background, some scholars have argued that rather than being promoted by left-wing parties, conservative parties and their upper-/upper-middle-income constituency expand public spending on higher education (Jensen 2011).

\section{THE (COMPLEX) POLITICS OF HIGHER EDUCATION: TOWARD CONDITIONAL PARTISAN MODELS}

Overall, then, a puzzle emerges. Do left-wing parties expand higher education (i.e., spending and enrollment) because it can provide socioeconomic and educational upward mobility? Or are right-wing parties the main proponent because it is mainly their constituency that benefits? To unravel these puzzling findings, a more recent literature challenges the perspective that the effect of parties is simple and linear by highlighting variation across time and across types of spending.

\section{Enrollment Levels Shape Politics}

A first important argument was that the influence of parties might depend on the institutional context. In an important contribution to the field, Ansell $(2008,2010)$ argued that political conflict over and effects of parties on higher education depend on the enrollment level (i.e., the proportion of each cohort attending higher-education schools). As long as enrollment levels are low, students mainly come from upper socioeconomic strata (as discussed previously). Thus, Ansell expected right-wing parties, representing these voters, to increase public higher-education spending, whereas leftwing parties would be opposed because their lower-income constituency is less likely to benefit. Instead, left-wing parties are theorized-following Marx's advice-to favor private of higher education-but enrollment itself is treated as exogenously given. The questions of why enrollment levels increase at all and why they should ever reach the "tipping point" remain somewhat understudied (particularly empirically). Conservative parties could anticipate this and stop the expansion before it reaches the tipping point-as happened, for example, in Japan.

More recent approaches tried to resolve these questions by disaggregating spending into different types. Garritzmann (2016) distinguishes public spending on higher-education institutions from spending on students (i.e., financial aid), arguing that both have different political dynamics. This distinction shows that public spending is not automatically fiscally regressive even when enrollment levels are low because governments can target spending to lower strata by investing in student financial aid. Thus, whereas Ansell's $(2008,2010)$ argument about reversing party positions might apply to public spending on higher-education institutions, it does not hold for more targeted spending on student aid. Empirically, this indeed is the case because qualitative and quantitative analyses reveal that left-wing governments in all advanced economies across the entire postwar period tried to increase spending on student financial aid, irrespective of the specific composition of the education system (Garritzmann 2016).

At the same time, distinguishing types of spending discounts the assumption that enrollment levels are exogenous to the political process. Left-wing parties can affect enrollment levels and the socioeconomic composition of the student body using financial aid. A broad sociopsychological literature confirms that student subsidies have strong positive effects on their enrollment decisions and studying behavior, particularly 
for lower-strata children (McPherson and Schapiro 2006). Of course, financial aid is not the only factor driving enrollment levels, but it is important-particularly for lower-strata children.

\section{The Four Worlds of Student Finance and Their Party-Political Origins}

Thus, a key insight from the newer literature was that when studying the partisan politics behind higher-education policies, we must consider that these might be conditional on the composition of the education system and the respective type of spending. So, how can we explain why countries' to establish subsidies and expand enrollment of lower-strata children. However, they were unsuccessful in these attempts in the long run because subsequent right-wing governments simply retrenched the subsidy spending and returned to the low-tuition-low-subsidy combination. In the fourth cluster, left-wing governments were in office long enough to establish student financial aid. It was therefore not feasible for subsequent right-wing governments to reestablish it (discussed in the next section). This was the case, for example, in the United States (Mettler 2002). ${ }^{2}$ Here, subsequent right-wing governments switched to their second-order preference, pushing for student loans instead of grants and allowing tuition increases.

\section{A broad sociopsychological literature confirms that student subsidies have strong positive effects on their enrollment decisions and studying behavior, particularly for lower-strata children (McPherson and Schapiro 2006).}

higher-education funding systems differ? This question is particularly pressing because in the immediate post-World War II period, the higher-education systems of all advanced democracies were still highly similar. Enrollment rates were approximately $2 \%$ to $5 \%$, tuition was absent or very low, and public student financial aid was nonexistent. Currently, however, "Four Worlds of Student Finance" (Garritzmann 2015, 2016) demonstrate very different combinations of public and private spending.

To explain why the advanced democracies developed such different higher-education systems, Garritzmann (2016)following Ansell and the previous literature-also identified governing parties as the key actor shaping them but points to the crucial role of a party's duration in office as well. He developed a "Time-Sensitive Partisan Theory" to explain the emergence of the Four Worlds.

In the first group of countries, left-wing parties were predominant in government throughout the entire postwar period (e.g., Sweden). Left-wing parties had already established student financial aid in the 1940 and 1950 , increased enrollment rates considerably (especially among formerly disadvantaged groups), and ensured that no tuition fees were required. Over time, these left-wing-dominated countries established low-tuition-high-subsidy systems. In the second country group, right-wing parties dominated office during the postwar decades (e.g., in Japan). These parties were more interested in maintaining the quality of their elite highereducation institutions than expanding access, so they focused resources on the few public elite schools and provided little support to other students. Consequently, the entire enrollment expansion was captured by the private sector, which naturally was highly tuition-dependent. Over time, therefore, right-wing-dominated countries developed high-tuition-lowsubsidy regimes.

In the third country cluster, exemplified by Germany, leftwing parties governed for only a short period before rightwing parties took back office. Left-wing parties thus tried
As a result, countries under this government composition today have high-tuition-high-subsidy systems.

The Time-Sensitive Partisan Theory finds strong empirical support in both historical comparative case studies over seven decades and in quantitative analyses of party positions, effects of parties on public and private spending, and public opinion (Garritzmann 2016). The partisan composition of governments and their duration in office can explain the historical emergence of the Four Worlds of Student Finance. Taken together, both Ansell $(2008,2010)$ and Garritzmann (2016) showed that the complex (re)distributive dynamics of higher education and the politics behind them can be disentangled once political conflict over education is considered in context.

\section{Why Policy Change Becomes Increasingly Difficult: That Is, Why "Tuition-Free College" Will Not Happen in the United States}

So far, this article has focused on the party-political origins of higher-education systems, showing how and under what conditions governing parties shaped them in line with their preferences. A final strand in the literature argued that although parties exercised significant influence on higher-education systems from the 1940 s to the 1980 os, their impact apparently has vanished in the more recent phase (Busemeyer 2015; Garritzmann and Seng 2016). Instead, all countries' highereducation systems have increasingly become path-dependent. Countries such as the United States and Japan, for example, which rely heavily on tuition fees, have further increased tuition, whereas there are no attempts to establish fees in tuition-free countries such as Finland and Germany. Why is this the case?

To explain this, a number of recent studies point to the power of "positive feedback effects," following Pierson's (1993) seminal work. Pierson argued that, over time, policies can "generate their own support" as beneficiary groups become vocal supporters, thereby making retrenchment 
increasingly unlikely. Mettler (2002) transferred these arguments to education, showing how in the United States, education policies shape public opinion and citizens' behavior. Busemeyer (2015) made similar arguments for Organization for Economic Cooperation and Development countries, which Garritzmann $(2015,2016)$ applied to higher education. He shows how, over time, public opinion adapts to a specific higher-education system, thereby making radical policy change increasingly costly for political parties.

In other words, the policy menu of political parties decreases over time. In tuition-free Scandinavia, for example, parties
United States) (Ness, Tandberg, and McLendon 2015). This might be due to the fact that in most advanced economies, the influence of vested interests on higher education might be weaker than that of governing parties; however, we simply do not know yet. Thus, future research could ask: How do parties and other politico-economic actors jointly shape higher-education systems?

Third, analysis of the partisan politics of higher education should be more closely related to those of other education sectors, such as vocational education, training, and child care. A comparison with child care seems especially

\section{In other words, the policy menu of political parties decreases over time. In tuition-free Scandinavia, for example, parties will simply not impose tuition because the large major- ity of voters strongly oppose private-education expenditure.}

will simply not impose tuition because the large majority of voters strongly oppose private-education expenditure. In the United States and Japan, in contrast, it is highly unlikely that policy makers could entirely abolish tuition fees; this would necessitate taxes hikes, which most voters oppose because they do not want to be charged "twice"-first for their own and then for another's education (Garritzmann 2015, 2016). In this vein, although Senator Bernie Sanders was successful in condemning the exorbitant tuition and student-debt amounts in the 2016 US primary campaigns, based on the existing literature, it is extremely unlikely that his ideas will materialize in concrete policies any time soon (however, see Eaton in this issue for regional exceptions).

\section{THE LITERATURE'S BLIND SPOTS-SOME OPEN QUESTIONS}

So far, the existing comparative literature on the role of political parties in higher-education policies has focused primarily on policy outcomes that are quantitatively comparable across countries and time (e.g., different types of public and private spending and enrollment levels). Many other interesting aspects have been disregarded-mainly because they are more difficult to capture empirically-and remain promising tasks for future research. First, do parties also affect highereducation governance, the quality of higher education, teaching content, research production, and other important outputs? In a recent explorative study, Jungblut (2016), for example, analyzed party positions on higher-education governance, showing that they also vary along party ideological lines. Thus, an interesting working hypothesis could be that whereas partisan influence on higher-education funding has decreased over time due to positive feedback effects, parties increasingly focus on affecting governance to continue shaping higher-education systems in line with their preferences.

Second, other political actors including unions, employer associations, and several types of interest groups do not feature prominently in the comparative literature; however, they are significant in some country-specific studies (e.g., in the worthwhile in this respect because both seem to follow a similar (re)distributive logic; use of child care is de facto also stratified by parental background (Van Lancker 2014). Thus, the politics of child care can be assumed to follow a similar logic as those of higher education. Projecting this way, more closely connecting the analysis of education and social policies seems to be a worthwhile task.

\section{DISCUSSION}

This article reviews the country-comparative literature on the partisan politics of higher education. It shows that due to the complex (re)distributive effects of higher-education policies, the politics behind them are not as straightforward as early contributions to the field assumed. Recent efforts in the field have begun unraveling the complex dynamics by situating partisan politics in context and by differentiating among several types of spending.

Overall, the country-comparative perspective has merit and draws implications not only for scholars but also for policy makers and practitioners. For one, the comparative perspective teaches us that political actors have significant room to maneuver as long as the higher-education systems are still in their infancy. Once the systems have developed in a particular direction (e.g., a strong tuition dependence), however, path dependencies prevail and radical policy change becomes increasingly costly for governing parties. ${ }^{3}$ Therefore, the careful design of the higher-education system is an extremely important and relevant factor during defining political moments (i.e., critical junctures).

In less abstract forms, consider the current debates in South Africa, Chile, and other emerging economies. Many advisorsparticularly economists-often stress that developing countries should establish tuition fees because the better-off are more likely to study (following Marx's argument). This is true, but it also is shortsighted advice. In the long run, this will probably lead to the persistence of inequalities because the everincreasing tuition fees that will be the consequence of such a policy (as shown in the path-dependency literature) will deter 
lower-strata children from studying (as shown in the sociopsychological and economic literature). Therefore, policy makers need to navigate carefully through these policy tradeoffs. The country-comparative perspective provides important lessons about the wide variety of available higher-education policies and their respective short- and long-term consequences.

\section{NOTES}

1. In this vein, the quantitative expansion of higher education does not necessarily imply more equality. Ahola (1995) showed that for the Finnish case (a least-likely case in this respect), for example, whereas enrollment levels increased among all socioeconomic strata, higherstrata children were more likely to study in more prestigious programs (e.g., medicine and law). Stated bluntly, we could argue that the stratification simply moved from "outside" the education sector "into" the higher-education sector.

2. Due to limited space, this article focuses on country-comparative literature and disregards country-specific studies. However, country-specific studie exist, particularly regarding the United States. For example, Doyle (2012) McLendon, Hearn, and Mokher (2009); and Ness, Tandberg, and McLendon (2015) explored variations across the US states.

3. The path-dependency argument applies particularly to radical and visible policy change. There still might be room for more subtle incrementalyet potentially also regime-transformative-policy change, in line with recent historical work on institutional change (Streeck and Thelen 2005). For example, the introduction of tuition fees for non-European Union/ European Economic Area students in some Scandinavian countries might become a "back door" to establish some type of tuition fees for other students as well. At present, however, there is no empirical sign of this because the involved political actors (especially student unions) articulate strong and vocal opposition, making it highly costly for political parties to proceed in this direction.

\section{REFEREN CES}

Ahola, Sakari. 1995. "From Elite to Mass Higher Education: Changing Structures of Selection in Finnish Higher Education." Rapportti zo. Turku, Finland: University of Turku, Unit for the Sociology of Education.

Ansell, Ben W. 2008. "University Challenges: Explaining Institutional Change in Higher Education." World Politics 6o (2): 189-230.

. 2010. From the Ballot to the Blackboard: The Redistributive Political Economy of Education. Cambridge: Cambridge University Press.

Boix, Carles. 1998. Political Parties, Growth and Equality: Conservative and Social Democratic Economic Strategies in the World Economy. Cambridge: Cambridge University Press.

Breen, Richard and Jan O. Jonsson. 2005. "Inequality of Opportunity in Comparative Perspective: Recent Research on Educational Attainment and Social Mobility." Annual Review of Sociology 31: 223-43.

Busemeyer, Marius R. 2009. "Social Democrats and the New Partisan Politics of Public Investment in Education." Journal of European Public Policy 16 (1): 107-26.

- 2015. Skills and Inequality: Partisan Politics and the Political Economy of Education Reforms in Western Welfare States. Cambridge: Cambridge University Press.
Busemeyer, Marius R. and Christine Trampusch. 2011. "Review Article: Comparative Political Science and the Study of Education." British Journal of Political Science 41 (2): 413-43.

Castles, Francis G. 1989. "Explaining Public Education Expenditure in OECD Countries." European Journal of Political Research 17 (4): 431-48.

Doyle, William E. 2012. "The Politics of Public College Tuition and State Financial Aid." Journal of Higher Education 83 (5): 617-47.

Eaton, Charlie. 2017. "Still Public: State Universities and America's New Student-Debt Coalitions.” PS: Political Science \& Politics 50 (2): this issue.

Fernandez, Raquel and Richard Rogerson. 1995. "On the Political Economy of Education Subsidies." Review of Economic Studies 62 (2): 249-62.

Garritzmann, Julian L. 2015. "Attitudes towards Student Support: How Positive Feedback Effects Prevent Change in the Four Worlds of Student Finance." Journal of European Social Policy 25 (2): 139-58.

- 2016. The Political Economy of Higher Education Finance: The Politics of Tuition Fees and Subsidies in OECD Countries, 1945-2015. Basingstoke, England: Palgrave Macmillan.

Garritzmann, Julian L. and Kilian Seng. 2016. "Party Politics and Education Spending: Challenging Some Common Wisdom." Journal of European Public Policy 23 (4): 510-30.

Iversen, Torben and John D. Stephens. 2008. "Partisan Politics, the Welfare State, and Three Worlds of Human Capital Formation." Comparative Political Studies 41 (4): 60o-637.

Jensen, Carsten. 2011. "Capitalist Systems, Deindustrialization, and the Politics of Public Education." Comparative Political Studies 44 (4): 412-35.

Jungblut, Jens. 2016. "Redistribution and Public Governance: The Politics of Higher Education in Western Europe." European Politics and Society $17(3): 331-52$.

Marx, Karl. 1973 [1890/1891]. “Kritik des Gothaer Programms.” In Werke. 4. Auflage, Karl Marx and Friedrich Engels 13-32. Berlin: Dietz.

McLendon, Michael K., James Hearn, and Christine G. Mokher. 2009. "Partisans, Professionals, and Power: The Role of Political Factors in State Higher Education Funding." Journal of Higher Education 8o (6): 686-713.

McPherson, Michael S. and Morton O. Schapiro. 2006. "US Higher Education Finance." In Handbook of the Economics of Education, Vol. 2, E. A. Hanushek and F. Welch (eds.), 1403-34. Amsterdam: North Holland-Elsevier.

Mettler, Suzanne. 2002. "Bringing the State Back into Civic Engagement: Policy Feedback Effects of the GI Bill for World War II Veterans." American Political Science Review 96 (2): 351-65.

Ness, Erik C., David A. Tandberg, and Michael K. McLendon. 2015. "Interest Groups and State Policy for Higher Education: New Conceptual Understandings and Future Research Directions." In Higher Education Handbook of Theory and Research 30, M. B. Paulsen (ed.), 151-86. New York: Springer Publishing Co.

Pierson, Paul. 1993. "When Effect Becomes Cause: Policy Feedback and Political Change." World Politics 54 (4): 595-628.

Streeck, Wolfgang and Kathleen Thelen. 2005. Beyond Continuity: Institutional Change in Advanced Political Economies. Oxford: Oxford University Press.

Van Lancker, Wim. 2014. To Whose Benefit? An Empirical and Comparative Investigation into the (Un)intended Consequences of Family Policy in the Social Investment State. Antwerp: University Press Antwerp.

Wilensky, Harold L. 1975. The Welfare State and Equality: Structural and Ideological Roots of Public Expenditures. Berkeley: University of California Press. 